\title{
Molecular epidemiology of Theileria equi in horses and their association with possible tick vectors in the state of Rio de Janeiro, Brazil
}

\author{
Maristela Peckle • Marcus S. Pires • \\ Tiago M. dos Santos • Erica C. R. Roier • \\ Claudia B. da Silva • Joice A. R. Vilela • \\ Huarrisson A. Santos • Carlos L. Massard
}

Received: 21 January 2013 / Accepted: 15 February 2013 /Published online: 9 March 2013

(C) The Author(s) 2013. This article is published with open access at Springerlink.com

\begin{abstract}
The aim of this study was to detect Theileria equi (Laveran 1901) DNA in horses and ticks using real-time PCR and to list the factors associated with infection in animals located in the Seropedica and Petropolis municipalities of the state of Rio de Janeiro. We tested blood samples from 314 horses and samples from 300 ticks, including 191 Amblyomma cajennense, 104 Dermacentor nitens, and 5 Ixodida larvae. Factors inherent to the horse, the ownership, and animal management were obtained from an epidemiological questionnaire and were evaluated in association with the presence of $T$. equi DNA in the animals. Among the horses in the study, $81 \%(n=253 / 314)$ presented $T$. equi DNA, and the animals of the Seropedica municipality had the highest infection frequency $(91 \%, n=128 / 141, p<$ $0.001)$. The factors that had significantly different infection frequencies by chi-squared or Fisher's exact tests $(p<0.2)$ were included in a logistic regression model using the $\mathrm{R}$ programming package. Work and walking activity (odds ratio $[\mathrm{OR}]=5.7, \mathrm{CI}=2.3-14.4)$, reproductive activity $(\mathrm{OR}=$ $3.8, \mathrm{CI}=1.3-11.5)$, and tick infestation $(\mathrm{OR}=2.6, \mathrm{CI}=1.1-$
\end{abstract}

M. Peckle $\cdot$ M. S. Pires • E. C. R. Roier $\cdot$ C. B. da Silva

J. A. R. Vilela $\cdot$ C. L. Massard $(\bowtie)$

Animal Parasitology Department, Veterinary Institute,

Universidade Federal Rural do Rio de Janeiro,

BR 465, Km 7, Seropédica,

Rio de Janeiro 23897-000, Brazil

e-mail: carlosmassard@ufrrj.br

T. M. dos Santos

Zootechny Department, Agricultural Science and Technology

Institute, Universidade Federal de Mato Grosso,

Rondonópolis, Brazil

H. A. Santos

Epidemiology and Public Health Department, Veterinary Institute,

Universidade Federal Rural do Rio de Janeiro, Seropédica, Brazil
6.2) were factors that favored the presence of $T$. equi DNA in the animals $(p<0.05)$. Among the tick samples, $A$. cajennense and $D$. nitens were the identified species. The presence of T. equi DNA was observed in $9.9 \%(n=19 / 191)$ of the A. cajennense samples and $3.8 \%(n=4 / 104)$ of the $D$. nitens samples. A multivariate analysis revealed that the presence of $A$. cajennense on the animals $(\mathrm{OR}=4.1, \mathrm{CI}=$ 1.8-9.1) was associated with the presence of T. equi DNA in the horses. In the studied municipalities, activities related to work, walking, and reproduction and the presence of ticks on the horses, particularly an intense infestation of $A$. cajennense, are factors that lead to infection with $T$. equi in the horses.

\section{Introduction}

Equine theileriosis is a disease caused by an intra-erythrocytic protozoan Theileria equi (Laveran 1901) (Mehlhorn and Schein 1998) and is characterized by fever, anemia, jaundice, hepatomegaly, splenomegaly, and hemoglobinuria. However, most infected animals became asymptomatic carriers, acting as a source of infection for tick vectors (De Waal 1992). In these animals, a low parasitemia level often precludes microscopic diagnosis by Giemsa-stained blood smears (Böse et al. 1995).

The worldwide problem of equine piroplasmosis is considered the main impediment to the international movement of horses because positive or seropositive animals are denied either entry for sports competitions or final export into several countries considered free of the disease (Knowles 1996; Friedhoff 1990).

The biological agent transmission occurs via the inoculation of sporozoites in horses by a tick vector. To date, ten tick species from three distinct genera (Dermacentor, 
Rhipicephalus, and Hyalomma) have been identified in $T$. equi transmission (Mehlhorn and Schein 1998). Until now in the Americas, Dermacentor variabilis and Rhipicephalus microplus (Canestrini 1887) have been tick species identified as transmitters of $T$. equi in experimental conditions (Stiller and Coan 1995; Guimarães et al. 1998a; Ueti et al. 2005; Ueti et al. 2008). In Latin America, horses are regularly infested with three species of ticks: Dermacentor nitens, Rhipicephalus microplus, and Amblyomma cajennense (Borges and Leite 1998; Labruna et al. 2001; Da Costa Pereira et al. 2005). R. microplus has been implicated as a vector (Guimarães et al. 1998a, b; Ueti et al. 2005), but it is a monoxenic tick, and T. equi transovarial transmission has not yet been reported. Thus, its epidemiological importance has been questioned. The role of D. nitens in the transmission of $T$. equi has not been reported (Denning 1988). In addition to biological transmission, congenital and iatrogenic forms of transmission have been observed (Tenter and Friedhoff 1986; Allsopp et al. 2007; Santos et al. 2008).

Theileria equi remains in the infected animal body for years and possibly throughout the animal's life (Mehlhorn and Schein 1998). Thus, the real-time polymerase chain reaction (qPCR), which is highly sensitive and specific, is a molecular technique that can be used to quantify the actual circulation of the agent in the studied area, in addition to allowing the quantification and investigation of circulating strains. Few studies have been conducted using molecular tools to investigate the epidemiological aspects of equine theileriosis in Brazil.

This study aimed to detect $T$. equi in horses and ticks by qPCR and to relate the variables about the host, environment and potential tick vectors to the presence of T. equi DNA in horses domiciled in the Seropedica and Petropolis municipalities of the state of Rio de Janeiro, Brazil.

\section{Materials and methods}

\section{Sampling}

From January to May 2009, 30 properties with horses in the Seropedica and Petropolis municipalities of the state of Rio de Janeiro, Brazil, were analyzed. The sampling was calculated according to an equation described by Sampaio (2002) , and the collection was performed by convenience in the studied area, with an assumed expected frequency of $59 \%$ (Heim et al. 2007), an error of $5 \%$ and an accuracy of $9 \%$. Blood samples were collected from 314 horses $(n=173$ in Petropolis and $n=141$ in Seropedica), and 300 samples were collected from ticks on these horses.

After the horse owners consented to the procedure, the animals were inspected for the presence of ticks, and the infestation level was assessed, followed by the collection of ticks. The blood samples were collected by jugular venipuncture and placed under vacuum in sterile tubes containing ethylenediamine tetraacetic acid (EDTA) anticoagulant.

An average of ten tick specimens in various developmental stages was collected from the different body parts of each infested animal. The taxonomic identification was based on the dichotomous keys of Aragão and Fonseca (1961) and Barros-Battesti et al. (2006). After identification, these specimens were stored in polypropylene tubes containing isopropyl alcohol according to the species, developmental stage, and sexual dimorphism. The infestation level of the ticks on the horses was measured subjectively based on the observation of adult tick specimens on the horses, categorized, and sorted into two infestation levels (absent/low or moderate/high) according to Labruna et al. (2001).

Epidemiological questionnaire

To assess the possible factors associated with infection by $T$. equi in the horses, a semi-structured questionnaire about the horses and the breeding and property management characteristics was administered to the owners. The factors investigated by the questionnaire were organized as follows: municipalities of Seropedica (low-altitude regions, less than $400 \mathrm{~m}$ in elevation) or Petropolis (high-altitude regions, more than $400 \mathrm{~m}$ in elevation); satisfactory or unsatisfactory zootechnical and sanitary management (Santos et al. 2011); presence or absence of ticks on animals; horses bred in close contact with cattle (cattle and horses shared the same pasture or were located close in proximity) or without contact with cattle; confined breeding system (confined system: animals had no access to outside areas and were restricted to the bay) or semi-confined/extensive system (limited access or total access to pasture areas); activities of the horses (sport/exhibition; work/walk or recreation; reproduction); gender (male or female); age ( $\leq 2$ years old or $>2$ years old); racial definition (breeded horses or mixed-breed horses).

\section{DNA extraction}

The extraction of deoxyribonucleic acid (DNA) from the blood samples was performed from $300 \mu \mathrm{L}$ of blood using the Wizard ${ }^{\circledR}$ Genomic DNA Purification kit according to manufacturer's recommendations.

For the DNA extraction from the tick samples, the specimens corresponding to each developmental stage were macerated in pools (nymphs $=$ ten copies; larvae $=$ ten copies; not engorged females $=$ two copies; males $=$ three copies), with the exception of the engorged females, which were macerated individually. After this step, genomic DNA was extracted based on the protocol for genomic DNA extraction according to Ferreira and Grattapaglia (1998). Each group 
of 11 samples had a control sample containing ultrapure water to rule out contamination during DNA extraction.

The DNA samples were resuspended in $200 \mu \mathrm{L}$ of TrisEDTA, quantified using the spectrophotometer Nanodrop $\mathrm{ND}-2000^{\circledR}$, standardized at a concentration of $60 \mathrm{ng} / \mu \mathrm{L}$ and stored at $-20{ }^{\circ} \mathrm{C}$ until use.

\section{Real-time PCR assay}

The detection of T. equi DNA was performed using a TaqMan PCR system in a Real-Time StepOne Plus ${ }^{\circledR}$ instrument to amplify the 81-bp fragment of the $18 S r R N A$ gene. The assay used the Be18SF (5'-GCGGTGTTTCGGTGATTCATA-3') and Be $18 \mathrm{SR}$ ( $5^{\prime}$ - T GATA GG TCA GAA A C T T GAATGATACATC-3') primer set and a fluorescent hydrolysis probe, Be18SP (5'-AAATTAGCGAATCGCATGGCTT$\left.3^{\prime}\right)$, which was labeled at the $5^{\prime}$ end with the reporter dye 6carboxyfluorescein and the 3' end with the quencher dye 6carboxy-tetramethylrhodamine (Kim et al. 2008). The reactions were performed in duplicate on different plates with a final volume of $12 \mu \mathrm{L}$, which contained: $1 \mathrm{X}$ TaqMan ${ }^{\circledR}$ Universal PCR Master Mix, $450 \mathrm{nM}$ of each primer, the $250 \mathrm{nM}$ of hydrolysis probe and $180 \mathrm{ng}$ of total DNA.

The thermocycling conditions were $50^{\circ} \mathrm{C}$ for $2 \mathrm{~min}, 95^{\circ} \mathrm{C}$ for $10 \mathrm{~min}$, and 45 cycles at $95^{\circ} \mathrm{C}$ for $20 \mathrm{~s}$, followed by $55^{\circ} \mathrm{C}$ for $1 \mathrm{~min}$ (Kim et al. 2008). The quantification cycle $\left(C_{\mathrm{q}}\right)$ was standardized between plates and was manually allocated three cycles after the fluorescence base. Samples with $C_{\mathrm{q}}$ values less than or equal to 40 cycles were considered positive.

The analytical sensitivity of the assay was determined by evaluating the serial decimal dilutions of the $18 S$ rRNA gene of $T$. equi cloned into the plasmid pGEM-T ${ }^{\circledR}$ Easy Vector System. The sensitivity of the real-time PCR was evaluated with and without the addition of $1 \mu \mathrm{L}$ of DNA from an uninfected blood sample and the addition of $1 \mu \mathrm{L}$ DNA from an uninfected tick. The concentration and purity of the plasmid DNA were measured by spectrophotometer Nanodrop ND-2000 ${ }^{\circledR}$. The concentration of the plasmid DNA was the basis for calculating the plasmid number. For determining the analytical sensitivity of the qPCR, a curve was created using five points, which were plotted as the number of copies of plasmid based on $C_{\mathrm{q}}$ values. The number of copies ranged from $3 \times 10^{4}$ to 3 , and four separate dilutions were performed for each point on the curve.

\section{Statistical analysis}

The horses' positivity for T. equi, as determined by qPCR, was examined for association with epidemiological questionnaire variables using the chi-squared or Fisher's exact tests at a $20 \%$ significance level.

Among the independent variables that were statistically significant $(p<0.20)$ in the bivariate analysis, the Spearman correlation test was applied to check the collinearity and to eliminate highly correlated variables from the logistic regression model. In this test, the independent variables with $p<0.05$ and $\rho<0.6$ were included in the multiple logistic regression model. Among the two highly correlated variables $(p<0,05$ and $\rho \geq 0,6)$, the one most biologically important was kept in the model.

A multiple logistic regression model was performed with the dependent variable (horses with molecular positivity for T. equi), which was dichotomous (negative $=0$, positive $=1$ ), as a function of the independent variables presented in the epidemiological questionnaire, at a $5 \%$ level of significance.

In the tick samples, the presence of the infectious agent DNA was evaluated according to the species collected (using the genus, evolutionary stage, and the studied municipalities) by the chi-squared or Fisher's exact tests at a $5 \%$ significance level.

For the verification of the isolated effect of the presence of a tick variable on the presence of T. equi DNA in horses, a logistic regression model was established using a qualitative dichotomous variable $($ absence $=0$ or presence $=1$ ) for each tick species in relation to the presence of $T$. equi DNA in the horses. Based on these results, another simple logistic regression model was created to evaluate the level of $A$. cajennense infestation according to the presence of $T$. equi DNA in the animals. This tick infestation level was a qualitative and dichotomous variable (absent/low $=0$ or moderate/high=1) (Labruna et al. 2001).

All final logistic regression models were analyzed by a likelihood ratio. Statistical analyses were performed using the $\mathrm{R}$ programming package within the graphical interface R-Studio (Development Core Team 2010, http://www.rproject.org).

\section{Results}

The analytical sensitivity of the qPCR technique was evaluated using a known number of copies of the vector-insert. The detection limit of the technique was three copies of the plasmid containing the $18 S$ rRNA gene. The determination coefficient of four replications of five dilutions tested in the standard curve was $99 \%$, with varying $C_{\mathrm{q}} 22.64 \pm 0.15$ cycles in the first dilution $\left(3 \times 10^{4}\right.$ copies of plasmid) to $35.73 \pm 0.38$ cycles in last dilution (three copies of the plasmid) (Fig. 1). No significant difference $(p>0.05)$ in analytical sensitivity when $1 \mu \mathrm{L}$ of uninfected equine blood and tick DNA was added to the PCR. The curves show the same slope during the exponential phase of the amplification reaction demonstrating the efficiency of $97.65 \%$, even a point with few targets (Fig. 2).

Of the equine analyzed samples, $81 \%(n=253 / 314)$ exhibited fragmented amplification of the $81 \mathrm{bp}$ of the $18 \mathrm{~S}$ $r R N A$ gene specific for $T$. equi by qPCR. With regard to the 


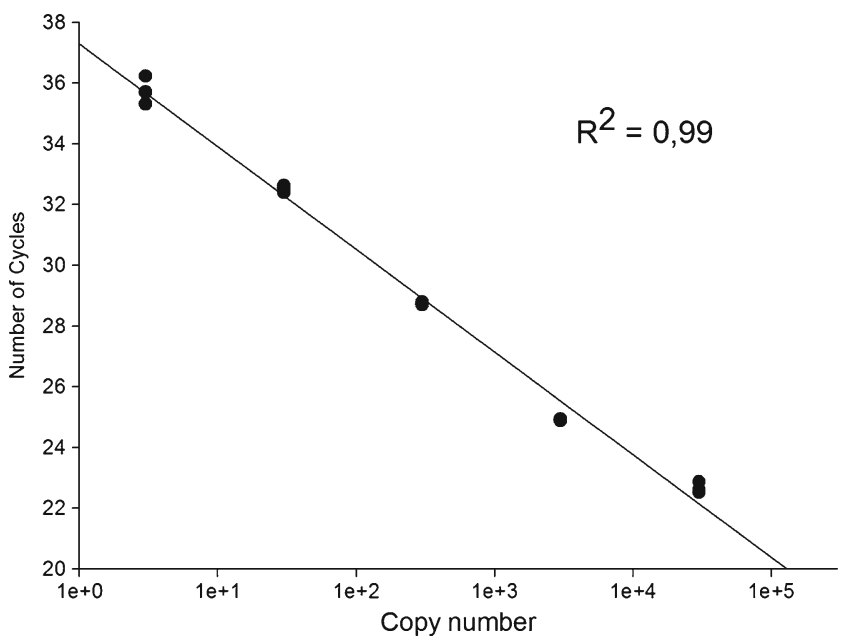

Fig. 1 Standard curve plotted from serial decimal dilutions of plasmid DNA, containing the Theileria equi $18 S \mathrm{rRNA}$ gene $(\sim 1,600 \mathrm{bp})$. The quantification cycle $\left(C_{\mathrm{q}}\right)$ value obtained by real-time polymerase chain reaction using Taqman system was plotted as a function of the initial number of plasmid copies

analyzed cities, $91 \%(n=128 / 141)$ of the horses in Seropedica were considered positive for T. equi, significantly higher $(p<$ $0.001)$ than the percentage of positive horses in Petropolis (72\%,n=125/173) (Table 1).

The variables inherent to equines, such as gender, racial definition, and age, were not associated with $T$. equi positivity $(p>0.20)$. However, with regard to variables related to ownership and breeding, municipality $(p<0.0001)$, property management $(p<0.00001)$, tick infestation of the animals $(p<0.0001)$, the horses in contact with cattle $(p=0.027)$, and the equine activity on-property $(p<0.0001)$ were associated with the presence of T. equi DNA in the samples $(p<0.20)$ (Table 1).

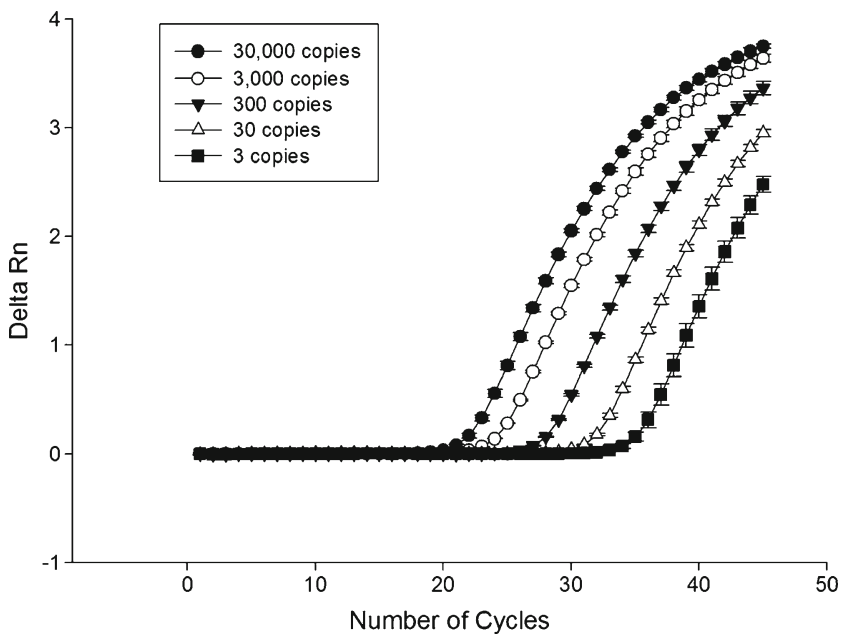

Fig. 2 Real-time polymerase chain reaction analytical sensitivity, showing the amplification curves of plasmid DNA, containing the Theileria equi $18 S$ rRNA gene $(\sim 1,600 \mathrm{bp})$, in serial dilutions (3-30,000 copies)
In the logistic regression model, only the equine activity on-property $(p<0.00001)$ and tick infestation $(p=0.02)$ were associated with $T$. equi infection. The property management variable $(p<0.00001)$ was removed from the multivariate analysis because it presented collinearity with the variable for the ticks infestation $(p<0.00001$ and $\rho=0.6)$.

Compared with the horses that had activities related to sports or exhibition, the horses with activities related to work (draft animals in agriculture, riding animals for cattle handling) or walking (people transportation and recreation) were 5.75 times (CI, 2.3-14.4) more likely to be infected by T. equi. The horses with reproductive activity were 3.8 times (CI, 1.3-11.5) more likely to have the infection. Horses with an infestation of ticks were 2.6 times (CI, 1.1-6.2) more likely to present $T$. equi DNA.

Tick infestations were identified in $51.3 \%(n=161 / 314)$ of the evaluated horses. A. cajennense and $D$. nitens were found on these infected horses with frequencies of $47.8 \%$ $(n=150 / 314)$ and $31.8 \%(n=100 / 314)$, respectively. Infestation with these two tick species was identified in $28.3 \%(n=89 / 314)$ of the evaluated horses. Among the 300 collected ticks, $63.7 \%(n=191 / 300)$ were identified as A. cajennense and $34.7 \%(n=104 / 300)$ as D. nitens. The ticks were primarily adults $(n=274 / 300,91.3 \%)$, followed by nymphs $(n=21 / 300,7 \%)$ and larvae $(n=5 / 300,1.7 \%)$. The specimens collected at an immature stage of development were identified taxonomically as larvae Ixodida. In relation to the ticks' gender, $61 \%(n=183 / 300)$ were identified as females and $30.3 \%(n=91 / 300)$ as males.

Regarding the detection of T. equi DNA in the evaluated ticks, $7.7 \%(n=23 / 300)$ of the ticks were positive. Furthermore, $9.9 \%(n=19 / 191)$ of the A. cajennense and $3.8 \%$ of the $D$. nitens $(n=4 / 104)$ had amplified the $81-\mathrm{bp}$ fragment from the T. equi $18 S \mathrm{rRNA}$ gene, with no statistically significant difference $(p=0.07)$ between the species (Table 2). Nevertheless, it is noteworthy that although not significantly different in frequency, the A. cajennense samples were 2.6 times more likely to be considered positive for $T$. equi than the $D$. nitens samples. The T. equi DNA fragment was not detected in the nymphs $(n=0 / 21)$ or larvae $(n=0 / 5)$ samples. The males were significantly more likely $(p<0.05)$ to be positive for T. equi $(15.4 \%, n=14 / 91)$ than the females $(4.9 \%, n=9 / 183)$. The males were more likely $(p<0.05)$ to be positive for T. equi $(18.2 \%, n=12 / 66)$ than the $A$. cajennense females $(5.8 \%, n=7 / 121)$. However, the $D$. nitens males $(8 \%, n=2 / 25)$ and females $(3.2 \%, n=2 / 62)$ did not significantly differ $(p>0.05)$ in their positivity for $T$. equi (Table 2).

The logistic regression model, which was applied to the tick species in relation to the presence of $T$. equi DNA in the horses, indicated that the horses infested with $A$. cajennense were four times more likely to harbor $T$. equi (Table 3 ). Using a simple logistic regression model to evaluate the $A$. 
Table 1 Bivariate and multivariate analysis of factors associated to Theileria equi infection in horses, by real-time PCR, according to animal characteristics, locality, zootechnical and sanitary management, contact with cattle, animals activity, breeding systems, ticks infestation in Petropolis and Seropedica municipalities, Rio de Janeiro, Brazil

\begin{tabular}{|c|c|c|c|c|c|c|c|}
\hline \multirow{2}{*}{$\begin{array}{l}\text { Characteristic of the } \\
\text { animals and management }\end{array}$} & \multicolumn{2}{|l|}{ Real-time PCR } & \multicolumn{2}{|c|}{ Bivariate } & \multicolumn{3}{|c|}{ Multivariate } \\
\hline & Number of animals sampled & Positives (\%) & $\chi^{2}$ & $P$ & $P$ & OR & CI $95 \%$ \\
\hline \multicolumn{8}{|l|}{ Gender } \\
\hline Male & 194 & 80.00 & \multirow[t]{2}{*}{0.003} & \multirow[t]{2}{*}{0.956} & \multirow[t]{2}{*}{-} & \multirow[t]{2}{*}{-} & \multirow[t]{2}{*}{-} \\
\hline Female & 120 & 80.93 & & & & & \\
\hline \multicolumn{8}{|l|}{ Age } \\
\hline$\leq 2$ years & 42 & 78.57 & \multirow[t]{2}{*}{0.020} & \multirow[t]{2}{*}{0.887} & \multirow[t]{2}{*}{-} & \multirow[t]{2}{*}{-} & \multirow[t]{2}{*}{-} \\
\hline$>2$ years & 272 & 80.88 & & & & & \\
\hline \multicolumn{8}{|l|}{ Racial definition } \\
\hline Mixed breed & 140 & 83.57 & \multirow[t]{2}{*}{0.444} & \multirow[t]{2}{*}{0.505} & \multirow[t]{2}{*}{-} & \multirow[t]{2}{*}{-} & \multirow[t]{2}{*}{-} \\
\hline Defined breed & 174 & 78.16 & & & & & \\
\hline \multicolumn{8}{|l|}{ Locality } \\
\hline Petropolis $(>400 \mathrm{~m})$ & 173 & 72.25 & \multirow[t]{2}{*}{15.870} & \multirow[t]{2}{*}{0.000} & $-^{\mathrm{a}}$ & & \\
\hline Seropedica $(<400 \mathrm{~m})$ & 141 & 90.78 & & & 0.39 & - & $0.6-3.2$ \\
\hline \multicolumn{8}{|c|}{ Zootechnical and sanitary management } \\
\hline Satisfactory & 150 & 66.67 & \multirow[t]{2}{*}{33.803} & \multirow[t]{2}{*}{$0.000^{\mathrm{b}}$} & - & \multirow[t]{2}{*}{-} & - \\
\hline Unsatisfactory & 164 & 93.29 & & & & & \\
\hline Contact with cattle & & & & & & & \\
\hline No & 218 & 77.06 & 4.900 & 0.027 & $-{ }^{\mathrm{a}}$ & & \\
\hline Yes & 96 & 88.54 & & & 0.48 & - & $0.2-1.8$ \\
\hline Activity & & & & & & & \\
\hline Sport/exposition & 118 & 61.02 & 46.200 & 0.000 & $-^{\mathrm{a}}$ & & \\
\hline Work/walk & 127 & 92.13 & & & 0.00 & 5.75 & $2.2-14.4$ \\
\hline Reproduction & 69 & 92.75 & & & 0.02 & 3.85 & $1.3-11.5$ \\
\hline Breeding system & & & & & & & \\
\hline Confined & 19 & 78.95 & - & $0.970^{\mathrm{c}}$ & - & - & - \\
\hline Extensive/semi-extensive & 295 & 78.64 & & & & & \\
\hline Ticks infestation & & & & & & & \\
\hline No & 153 & 67.97 & 28.713 & 0.000 & $-^{\mathrm{a}}$ & & \\
\hline Yes & 161 & 92.55 & & & 0.03 & 2.63 & $1.1-6.2$ \\
\hline Animals' origin & & & & & & & \\
\hline Inside property & 98 & 84.69 & 1.186 & 0.276 & - & - & - \\
\hline Outside property & 216 & 78.70 & & & & & \\
\hline
\end{tabular}

$\chi^{2}$ value of chi-square test, $P p$ value, $O R$ odds ratio, $C I$ confidence interval

${ }^{\text {a }}$ Category reference

${ }^{\mathrm{b}}$ Removed from the multivariate analysis due to collinearity verified by Spearman test

${ }^{\mathrm{c}}$ Fisher's exact test

cajennense infestation level in comparison with the animals' positivity, the horses with moderate to high infestation were 2.7 times more likely to have T. equi DNA than the horses with low-level or no A. cajennense infestation (Table 4).

\section{Discussion}

This epidemiological study reinforces the endemic character that equine theileriosis assumes in Brazil (Pfeifer-Barbosa et al. 1995; Heuchert et al. 1999; Golynski et al. 2008; Kerber et al. 2009; Santos et al. 2011). In addition, this study highlights the possible factors relevant to properties, breed management, and animal characteristics that are associated with $T$. equi presence in horses. It also demonstrates the importance of epidemiology as a vector research tool to understand the possible role of other tick species in addition to $R$. microplus in the transmission and spread of T. equi in Brazil.

The high frequency of $T$. equi among the horses in the studied municipalities is in agreement with several 
Table 2 Bivariate analysis of factors associated to Theileria equi infection in tick samples, by real-time PCR, according to samples characteristics, as locality, identified species, developmental stage, and tick gender in the state of Rio de Janeiro, Brazil

\begin{tabular}{|c|c|c|c|c|}
\hline \multirow{2}{*}{$\begin{array}{l}\text { Tick samples } \\
\text { characteristics }\end{array}$} & \multicolumn{2}{|c|}{ Real-time PCR } & \multicolumn{2}{|c|}{ Bivariate } \\
\hline & $\begin{array}{l}\text { Number of } \\
\text { animals } \\
\text { sampled }\end{array}$ & Positives (\%) & $\chi^{2}$ & $P$ \\
\hline \multicolumn{5}{|l|}{ Altitude } \\
\hline $\begin{array}{l}<400 \text { m (Seropedica) } \\
>400 \text { m (Petropolis) }\end{array}$ & $\begin{array}{l}238 \\
62\end{array}$ & $\begin{array}{l}6.69 \\
11.29\end{array}$ & - & 0.28 \\
\hline \multicolumn{5}{|l|}{ Species } \\
\hline $\begin{array}{l}\text { Amblyomma cajennense } \\
\text { Dermacentor nitens }\end{array}$ & $\begin{array}{l}191 \\
104\end{array}$ & $\begin{array}{l}9.95 \\
3.85\end{array}$ & 3.96 & $0.07^{\circ}$ \\
\hline \multicolumn{5}{|l|}{ Developmental stage } \\
\hline $\begin{array}{l}\text { Adults } \\
\text { Nymphs }\end{array}$ & $\begin{array}{l}274 \\
21\end{array}$ & $\begin{array}{l}8.39 \\
0.00\end{array}$ & \multirow[t]{2}{*}{2.36} & \multirow[t]{2}{*}{0.31} \\
\hline Larvae & 5 & 0.00 & & \\
\hline \multicolumn{5}{|l|}{ Gender } \\
\hline $\begin{array}{l}\text { Male } \\
\text { Female }\end{array}$ & $\begin{array}{l}91 \\
183\end{array}$ & $\begin{array}{l}15.38 \\
4.92\end{array}$ & 11.77 & 0.00 \\
\hline \multicolumn{5}{|l|}{ Amblyomma cajennense } \\
\hline $\begin{array}{l}\text { Male } \\
\text { Female }\end{array}$ & $\begin{array}{l}66 \\
121\end{array}$ & $\begin{array}{l}18.18 \\
5.79\end{array}$ & \multirow[t]{2}{*}{7.78} & \multirow[t]{2}{*}{0.02} \\
\hline Nymphs & 4 & 0.00 & & \\
\hline \multicolumn{5}{|l|}{ Dermacentor nitens } \\
\hline $\begin{array}{l}\text { Male } \\
\text { Female }\end{array}$ & $\begin{array}{l}25 \\
62\end{array}$ & $\begin{array}{l}8.00 \\
3.23\end{array}$ & \multirow[t]{2}{*}{1.91} & \multirow[t]{2}{*}{0.38} \\
\hline Nymphs & 17 & 0.00 & & \\
\hline
\end{tabular}

$\chi^{2}$ value of chi-square test, $P p$ value

${ }^{a}$ Fisher's exact test

serological studies conducted in areas located near the studied municipalities (Pfeifer-Barbosa et al. 1995; Santos et al.

Table 3 Multivariate analysis of Theileria equi positivity in horses by real-time PCR, in relation to the tick species observed on animals in the state of Rio de Janeiro, Brazil

\begin{tabular}{|c|c|c|c|c|c|}
\hline \multirow[t]{2}{*}{ Ticks } & \multicolumn{2}{|l|}{ Real-time PCR } & \multicolumn{3}{|c|}{ Multivariate } \\
\hline & $\begin{array}{l}\text { Number of } \\
\text { animals sampled }\end{array}$ & $\begin{array}{l}\text { Positives } \\
(\%)\end{array}$ & $P$ & OR & $\mathrm{CI}$ \\
\hline \multicolumn{6}{|c|}{ Amblyomma cajennense } \\
\hline Yes & 150 & 92.7 & 0.00 & 4.10 & $(1.8-9.1)$ \\
\hline No & 164 & 69.5 & $-^{\mathrm{a}}$ & - & - \\
\hline \multicolumn{6}{|c|}{ Dermacentor nitens } \\
\hline Yes & 100 & 93.0 & 0.18 & - & - \\
\hline No & 214 & 74.8 & $-^{\mathrm{a}}$ & - & - \\
\hline
\end{tabular}

$P p$ value, $O R$ odds ratio, $C I$ confidence interval

${ }^{\mathrm{a}}$ Category reference
Table 4 Simple logistic regression model to evaluate the Amblyomma cajennense infestation level in comparison with the animals' positivity for Theileria equi in the state of Rio de Janeiro, Brazil

\begin{tabular}{lllllll}
\hline $\begin{array}{l}\text { Amblyomma } \\
\text { cajennense }\end{array}$ & \multicolumn{2}{l}{ Real-time PCR } & & \multicolumn{2}{l}{ Logistic regression } \\
\cline { 2 - 3 } \cline { 5 - 7 } & $\begin{array}{l}\text { Number of } \\
\text { animals } \\
\text { sampled }\end{array}$ & $\begin{array}{l}\text { Positives } \\
(\%)\end{array}$ & & & OR & CI \\
\hline Infestation level & & & & & \\
Moderate/many & 74 & 90.5 & & 0.01 & 2.77 & $(1.2-6.4)$ \\
None/few & 240 & 77.5 & & $-{ }^{\mathrm{a}}$ & - & - \\
\hline
\end{tabular}

$P p$ value, $O R$ odds ratio, $C I$ confidence interval

${ }^{\mathrm{a}}$ Category reference

2011). However, importantly, this study detected T. equi DNA using qPCR, a highly sensitive and specific technique used in many molecular epidemiology investigations (Monis et al. 2005).

The municipality of Seropedica, which is located in the low-altitude region of the state of Rio de Janeiro, has a semihumid tropical climate, with an annual average temperature of approximately $24{ }^{\circ} \mathrm{C}$. In contrast, the municipality of Petropolis, which is located in the high-altitude region of the state, has a tropical climate and an annual average temperature of approximately $16{ }^{\circ} \mathrm{C}$, with winter temperatures that may reach $0{ }^{\circ} \mathrm{C}$. The conditions encountered by tick vectors in high-altitude cities such as Petropolis are less favorable for their development and reproduction, which contributed to the lower tick infestation and the lower frequency of $T$. equi infection in the horses in that location (Davey and Cooksey 1989; Chacón et al. 2003). Furthermore, management conditions and the quality of the properties found in Petropolis are better than those of properties in Seropedica.

According to the bivariate analysis, the T. equi positivity of the horses bred in close contact with cattle was significantly different from the T. equi positivity of the horses bred in the absence of cattle. This observation suggests a possible involvement of $R$. microplus on the epidemiological chain of equine theileriosis in the studied region. Experimental studies indicate that $R$. microplus is capable of being infected and is capable of transmitting the equine theileriosis agent when feeding on horses chronically infected or with an acute infection of T. equi (Guimarães et al. 1998a, b; Stiller et al. 2002; Ueti et al. 2008). Furthermore, horses with an infestation of $R$. microplus have been observed in areas where cattle graze (Bittencourt 1990; Labruna et al. 2001). However, it is unlikely that $R$. microplus plays an important role in the equine theileriosis enzootic cycle in the studied region because this study found no horses infested by this tick species. Perhaps other forms of transmission or 
other arthropods may be involved in maintaining the high level of the disease observed in the studied area.

The horses activities related to work, walking, and reproduction were factors that determined the infection with T. equi. This finding was observed by Abutarbush et al. (2012), in which the animals used for work showed a higher frequency of T. equi positivity, which differed significantly from other variables, such as the animals raised for practicing polo, running, jumping, reproduction, and exposure. These findings may also be related to the activities that the horse exerts on the property, where in many cases, the animals with work or walking activities also move into large pasture perimeters and increase their chances of infestation by potential tick vectors. Furthermore, animals with work, walking, and reproduction activities often live on properties that have poor management (Santos et al. 2011; Heuchert et al. 1999), are in close contact with cattle in pastures infested by different tick species (Heuchert et al. 1999), and have a grazing habit (Abutarbush et al. 2012; Nizoli et al. 2008), so they are at increased risk of contact with tick vectors. In our study, we observed that animals destined for sports and exposure activities receive management considered ideal for these types of breeding, with appropriate zootechnical buildings where the animals receive balanced meals, systematic veterinary care, and sanitary control; thus, they are at decreased risk of tick vector infestation.

The experimental transmission of $T$. equi is associated with Rhipicephalus ticks (Guimarães et al. 1998a, b; Stiller and Coan 1995; De Waal 1992; Ueti et al. 2005). However, to date, there are no reports that demonstrate the truly natural vector of this etiologic agent of importance in horses worldwide. Studies suggest that the species $A$. cajennense can act as a natural vector (Scoles et al. 2011; Kerber et al. 2009) of this agent because of its increased dispersion and predilection for horses. Nevertheless, in an experimental study conducted by Ribeiro et al. (2011), T. equi infection was not observed in A. cajennense that fed on horses with an acute or chronic infection. This study demonstrated that $A$. cajennense is associated with the presence of $T$. equi DNA in horses, but the participation of $A$. cajennense as a natural vector remains unclear. Thus, the high frequency of $A$. cajennense infestation among the horses may be considered a confounding factor in the epidemiological analysis. In support of this confounding factor are studies demonstrating that $T$. equi can be transmitted congenitally in equines (Santos et al. 2008), making vector investigation through epidemiological analysis difficult. However, in a study conducted in Texas in the USA, Scoles et al. (2011) found that A. cajennense was capable of becoming naturally infected by $T$. equi and was able to experimentally transmit it when feeding on infection-free horses, demonstrating that T. equi can be transmitted in an interstadial way by this tick species.
In this study, $A$. cajennense males were significantly more likely than females to have $T$. equi DNA. The $A$. cajennense males are able to feed on various hosts during their lifecycle, increasing their chances of becoming infected with $T$. equi, and they survive for long fasting periods (Serra-Freire 1982; Oliveira et al. 2003). These characteristics make them important transmitters of etiologic agents in animals and humans.

The high frequency of $T$. equi in horses in Brazil and around the world suggests that the natural vector is abundant among the animals, is common in all locations where horse breeding occurs, and is capable of transmitting T. equi from an infected animal to a susceptible one. Therefore, epidemiologically, $A$. cajennense could be a suitable vector in the studied area because it requires three hosts to complete its life cycle, is distributed throughout the Americas, and seems to prefer horses as the hosts for all parasitic stages (Aragão 1936; Oliveira et al. 2000). In this study, the horses infested with A. cajennense at moderate or high levels were more likely to be infected with T. equi, corroborating previous findings.

The qPCR technique was an excellent tool for epidemiological hemoparasite investigation because $T$. equi has a chronic nature in the equine organism. Infestation by ticks and animal activities are factors associated with $T$. equi infection in the studied region. Among the investigated ticks, A. cajennense was the species epidemiologically regarded as a potential biological vector of this piroplasma under natural conditions in the studied area.

Acknowledgments The authors thank the owners of the animals used in the study, due to availability, trust, and patience. This research was supported by National Council for Scientific and Technological Development (CNPq) of Brazil, 'Carlos Chagas Filho' Foundation for Research Support of the State of Rio de Janeiro (FAPERJ), and Coordination of Improvement of Higher Education Personnel (CAPES) funds. The authors are also grateful for the statistical assistance provided by Professor Wagner Tassinari (Mathematics Department at Universidade Federal Rural do Rio de Janeiro).

Open Access This article is distributed under the terms of the Creative Commons Attribution License which permits any use, distribution, and reproduction in any medium, provided the original author(s) and the source are credited.

\section{References}

Abutarbush SM, Alqawasmeh DM, Mukbel RM, Al-Majali AM (2012) Equine Babesiosis: seroprevalence, risk factors and comparison of different diagnostic methods in Jordan. Transbound Emerg Dis 59:72-78. doi:10.1111/j.1865-1682.2011.01244.x

Allsopp MTEP, Lewis BD, Penzhorn BL (2007) Molecular evidence for transplacental transmission of Theileria equi from carrier mares to their apparently healthy foals. Vet Parasitol 148:130 136. doi:10.1016/j.vetpar.2007.05.017 
Aragão H (1936) Ixodidas brasileiros e de alguns paizes limitrophes. Mem Inst Oswaldo Cruz 31:759-843. doi:10.1590/S007402761936000400004

Aragão H, Fonseca F (1961) Notas de Ixodologia. VIII lista e chave para os representantes para a fauna ixodológica brasileira. Mem Inst Oswaldo Cruz 59:115-129. doi:10.1590/S007402761961000200001

Barros-Battesti DM, Arzua M, Bechara GH (2006) Carrapatos de Importância Médico-Veterinária da Região Neotropical: Um guia ilustrado para identificação de espécies. VOX/ICTTD-3/ BUTANTAN,São Paulo

Bittencourt AJ (1990) Boophilus microplus (Canestrini, 1887): (Infestações artificiais, biologia da fase não parasitária e prevalências em caprinos e equinos). Dissertation, Universidade Federal Rural do Rio de Janeiro

Böse R, Jorgensen WK, Dalgliesh RJ, Friehoff KT, De Vos AJ (1995) Current state and future trends in the diagnosis of babesiosis. Vet Parasitol 57:61-74. doi:10.1016/0304-4017(94)03111-9

Borges LMF, Leite RC (1998) Ixodological populations of the ears of equines in Minas Gerais and Bahia, Brazil. Braz J Vet Anim Sci 50:87-89

Chacón SC, Correia PG, Barbieri FS, Daemon E, Faccini JLH (2003) Efeito de três temperaturas constantes sobre a fase não parasitária de Amblyomma cajennense (Fabricius, 1787) (Acari: ixodidae). Braz J Vet Parasitol 12:13-20

Da Costa Pereira MAV, Massard CL, Faccini JLH, Siqueira LFG (2005) Variação da sorotitulação ao teste de Fixação de Complemento para Babesia equi e Babesia caballi em equinos da região Serrana do Rio de Janeiro. Ars Vet 21:338-343

Davey RB, Cooksey LM (1989) Effects of prolonged exposure at low temperature on Boophilus microplus (Acari: Ixodidae). J Med Entomol 26:407-410

De Waal DT (1992) Equine piroplasmosis: a review. Br Vet J 148:614. doi:10.1016/0007-1935(92)90061-5

Denning F (1988) Unsuccessful attempts at transmission of Babesia equi by Anocentor nitens and Amblyomma cajennense. Dissertation, Hannover Veterinary College.

Ferreira ME, Grattapaglia D (1998) Introdução ao uso de marcadores moleculares em análise genética. EMBRAPA-CENARGEN, Brasil

Friedhoff KT, Tenter AM, Muller I (1990) Haemoparasites of equines: impact on international trade of horses. Rev Sci Tech 9:1187-1194

Golynski AA, Fernandes KR, Baldani CD, Golynski AL, Madeiro AS, Machado RZ, Botteon PTL, Massard CL (2008) Estudo soroepidemiológico da Babesia equi em equinos do estado do Rio Grande do Sul, Brasil, determinado pelos testes de imunofluorescência indireta e Elisa. Braz J Vet Parasitol 17:317-321. doi:10.1590/S1984-29612010000100001

Guimarães AM, Lima JD, Ribeiro MFB, Camargos ERS, Bozzi IA (1998a) Ultrastructure of sporogony in Babesia equi in salivary glands of adult female Boophilus microplus ticks. Parasitol Res 60:69-74. doi:10.1007/s004360050359

Guimarães AM, Lima JD, Ribeiro MFB (1998b) Sporogony and experimental transmission of Babesia equi by Boophilus microplus. Parasitol Res 84:323-327. doi:10.1007/s004360050404

Heim A, Passos LF, Ribeiro MFB, Costa-Júnior L, Bastos CV, Cabral DD, Hirzmann J, Pfister K (2007) Detection and molecular characterization of Babesia caballi and Theileria equi isolates from endemic areas of Brazil. Parasitol Re 102:63-68. doi:10.1007/s00436-007-0726-1

Heuchert CMS, Giulli V, Athaide DF, Böse R, Friedhoff KT (1999) Seroepidemiologic studies on Babesia equi and Babesia caballi infections in Brazil. Vet Parasitol 85:1-11. doi:10.1016/S03044017(99)00108-9

Kerber CE, Labruna MB, Ferreira F, De Waal DT, Knowles DP, Gennari SM (2009) Prevalence of equine Piroplasmosis and its association with tick infestation in the state of São Paulo, Brazil. Braz J Vet Parasitol 18:1-8. doi:10.4322/rbpv.01804001
Kim C, Blanco LBC, Alhassan A, Iseki H, Yokoyama N, Xuan X, Igarashi I (2008) Diagnostic real-time PCR assay for the quantitative detection of Theileria equi from equine blood samples. Vet Parasitol 151:158-163. doi:10.1016/j.vetpar.2007.10.023

Knowles D Jr (1996) Equine babesiosis (Piroplasmosis): a problem in the international movement of horses. Br Vet J 52:123-126

Labruna MB, Kerber CE, Ferreira F, Faccini JLH, De Waal DT, Genari SN (2001) Risk factors to tick infestations and their occurrence on horses in the state of São Paulo, Brazil. Vet Parasitol 97:1-14. doi:10.1016/S0304-4017(01)00387-9

Mehlhorn H, Schein E (1998) Redescription of Babesia equi Laveran, 1901 as Theileria equi Mehlhorn, Schein 1998. Parasitol Res 84:467-475. doi:10.1007/s004360050431

Monis PT, Giglio S, Keegan AR, Thompson RCA (2005) Emerging technologies for the detection and genetic characterization of protozoan parasites. Trends Parasitol 21:340-346. doi:10.1016/ j.pt.2005.05.012

Nizoli LQ, Götze MM, Félix SR, Silva SS, Nogueira CEW (2008) Frequency of seropositive equines for Theileria equi in the southern Rio Grande do Sul State, Brazil. Parasitol Latinoam 63:46-50. doi: $10.4067 / \mathrm{S} 0717-77122008000100008$

Oliveira PR, Borges LMF, Leite RC, Freitas CMV (2003) Seasonal dynamics of the Cayenne tick, Amblyomma cajennense on horses in Brazil. Med Vet Entomol 17:412-416. doi:10.1111/j.13652915.2003.00459.x

Oliveira PR, Borges LMF, Lopes CML, Leite RC (2000) Population dynamics of the free-living stages of Amblyomma cajennense (Fabricius, 1787) (Acari: Ixodidae) on pastures of Pedro Leopoldo, Minas Gerais State, Brazil. Vet Parasitol 92:295-301. doi:10.1016/S0304-4017(00)00322-8

Pfeifer-Barbosa IB, Bose R, Peymann B, Friedhoff KT (1995) Epidemiological aspects of equine babesioses in a herd of horses in Brazil. Vet Parasitol 58:1-8. doi:10.1016/0304-4017(94)00704-G

R Development Core Team (2010) R: a language and environment for statistical computing. R Fundation for Statistical Computing, Vienna, Austria. http://www.r-projetc.org. Accessed 31 jan 2010

Ribeiro MFB, Silveira JAG, Bastos CV (2011) Failure of the Amblyomma cajennense nymph to become infected by Theileria equi after feeding on acute or chronically infected horses. Exp Parasitol 128:324-327. doi:10.1016/j.exppara.2011.03.016

Sampaio IBM (2002) Estatística aplicada à experimentação animal. FEPMVZ, Belo Horizonte

Santos TM, Santos HA, Massard CL (2008) Diagnóstico molecular de babesiose congênita em potros neonatos no estado do Rio de Janeiro, Brasil. Braz J Vet Parasitol 17:348-350. doi:10.1590/ S1984-29612010000100001

Santos TM, Roier ECR, Santos HA, Pires MS, Vilela JAR, Moraes LMB, Almeida FQ, Baldani CD, Machado RZ, Massard CL (2011) Factors associated to Theileria equi in equids of two microregions from Rio de Janeiro, Brazil. Braz J Vet Parasitol 20:235-241. doi:10.1590/S1984-29612011000300011

Scoles GA, Hutcheson HJ, Schlater JL, Hennager SG, Pelzel AM, Knowles PD (2011) Equine piroplasmosis associated with Amblyomma cajennense ticks, Texas, USA. Emerg Infect 17:1903-1905. doi:10.3201/eid1710.101182

Serra-Freire NM (1982) Epidemiologia de Amblyomma cajennense: Ocorrência estacional e comportamento dos estágios não parasitários em pastagens do Estado do Rio de Janeiro. Arq Univ Fed Rural Rio Jan 5:187-193

Stiller D, Coan ME (1995) Recent developments in elucidating tick vector relationships for anaplasmosis and equine piroplasmosis. Vet Parasitol 57:97-108. doi:10.1016/0304-4017(94)03114-C

Stiller D, Goff WL, Johnson LW, Knowles DP (2002) Dermacentor variabilis and Boophilus microplus (Acari: Ixodidae): experimental vectors of Babesia equi to equids. J Med Entomol 39:667-670. doi:10.1603/0022-2585-39.4.667 
Tenter AM, Friedhoff KT (1986) Serodiagnosis of experimental and natural Babesia equi and B. caballi infections. Vet Parasitol 20:49-61. doi:10.1016/0304-4017(86)90092-0

Ueti WM, Palmer GH, Kappmeyer LS, Statfield M, Scoles GA, Knowles PD (2005) Ability of vector tick Boophilus microplus to acquire and transmit Babesia equi following feeding on chronically infected horses with low-level parasitemia. J Clin Microbiol 43:3755-3759. doi:10.1128/ JCM.43.8.3755-3759.2005

Ueti WM, Palmer GH, Scoles GA, Kappmeyer LS, Knowles PD (2008) Persistently infected horses are reservoirs for intrastadial tick-borne transmission of the apicomplexan parasite Babesia equi. Infect Immun 76:3525-3529. doi:10.1128/ IAI.00251-08 